\title{
Interaction Between Single Nucleotide Polymorphism in Catalase Gene and Catalase Activity Under the Conditions of Oxidative Stress
}

\author{
A. V. KOMINA ${ }^{1}$, K. A. KOROSTILEVA ${ }^{1}$, S. N. GYRYLOVA ${ }^{1}$, R. N. BELONOGOV ${ }^{1}$, \\ T. G. RUKSHA ${ }^{1}$
}

${ }^{1}$ Department of Pathophysiology, Krasnoyarsk State Medical University Named After V. F. VoinoYasenetsky, Russian Federation Ministry for Health and Social Development, Krasnoyarsk, Russia

Received February 7, 2012

Accepted August 3, 2012

On-line October 25, 2012

\section{Summary}

Catalase is an antioxidant enzyme the activity of which is crucial for the protection against damage caused by reactive oxygen species. The $-262 \mathrm{C}>\mathrm{T}$ polymorphism in the promoter region of catalase gene was found to be associated with altered catalase levels. In this study, peripheral blood mononuclear cells catalase activity was measured after $\mathrm{H}_{2} \mathrm{O}_{2}$-induced oxidative stress. $\mathrm{C} / \mathrm{T}$ and $T / T$ genotypes were associated with the decrease of catalase levels in contrast to $\mathrm{C} / \mathrm{C}$ donors who had elevated catalase activity in the presence of 0.4 and $0.7 \mathrm{mM} \mathrm{H}_{2} \mathrm{O}_{2}$. Genotypedependent response of catalase activity to oxidative stress might be related to the predisposition of catalase mutant allele carriers to disorders mediated by oxidative stress.
\end{abstract}

\section{Key words}

Catalase • Polymorphism • Free radicals $\bullet \mathrm{H}_{2} \mathrm{O}_{2}$

\section{Corresponding author}

T. Ruksha, State Medical University, P. Zeleznyaka str. 1, Krasnoyarsk, Russia, 660022. E-mail: tatyana_ruksha@mail.ru

Catalase is an antioxidant enzyme responsible for $\mathrm{H}_{2} \mathrm{O}_{2}$ conversion into oxygen and water (Ahn et al. 2006). Catalase uses hydrogen peroxide as a source of electrons and is expressed in almost all types of eukaryotic cells. It is considered to be the most important regulator of $\mathrm{H}_{2} \mathrm{O}_{2}$ metabolism. $\mathrm{H}_{2} \mathrm{O}_{2}$ in high concentrations could be toxic to cells and it modulates some physiological processes such as cell proliferation, apoptosis, and platelet activation at low concentrations (Labios et al. 2009). Catalase gene polymorphism in promoter region $(-262 \mathrm{C}>\mathrm{T})$ affects transcription factor binding and thus decreases catalase enzymatic activity leading to increased formation of hydroxyl radicals and elevated risk of breast cancer development, asbestosis, and arsenic-induced hyperkeratosis (Ahn et al. 2005, Mak et al. 2007, Franko et al. 2008). Another study revealed the increased frequency of mutant catalase genotype in patients with pseudoxanthoma elasticum - rare hereditary skin disorder caused by progressive alterations of connective tissue including calcification and fragmentation of elastic fibers (Zarbock et al. 2007). In addition, catalase gene mutation in exon 9 is associated with vitiligo development - skin disease caused by oxidative stress damage of melanocytes followed by a progressive loss of skin pigment produced by them (Casp et al. 2002, Schallreuter et al. 2012).

Catalase is not the only enzyme responsible for $\mathrm{H}_{2} \mathrm{O}_{2}$ metabolism, because thioredoxin reductase and glutathione peroxidase are also major antioxidant tools against $\mathrm{H}_{2} \mathrm{O}_{2}$-mediated stress (Schallreuter and Wood 2001). Glutathione peroxidase seems to be the major enzyme for detoxification of $\mathrm{H}_{2} \mathrm{O}_{2}$ under the normal conditions (Chabory et al. 2010). Catalase plays a more significant role in protecting cells against severe oxidative stress (Kinnula et al. 1992).

The aim of our research was to evaluate catalase polymorphism distribution in healthy voluntaries of Krasnoyarsk Territory, Siberian Federal District of 
Russian Federation and to estimate catalase activity in persons with different catalase genotype under the oxidative stress conditions induced by $\mathrm{H}_{2} \mathrm{O}_{2}$.

\section{RFLP analysis}

The study was approved by Local Ethic Committee of Krasnoyarsk State Medical University named after Prof. V. F. Voino-Yasenetsky. Blood samples from 103 healthy adult voluntaries (78 women and $25 \mathrm{men}$ ) in the age ranging from 19 to 53 years were processed for DNA isolation. Genomic DNA was extracted from whole blood by DNA-sorb B isolation kit (AmpliSens, Russia). The primer sequences were CTGATAACCGGGAGCCCCGCCCTGGGTTCGGA TAT-3' and 5'-CTAGGCAGGCCAAGATTGGAAGC CCAATGG-3' (SibEnzyme, Russia) constructed as described by Zarbock et al. (2007) for creation of the restriction site for EcoR $\mathrm{V}$ in wild allele (GATATC). The cycling conditions were: $95^{\circ} \mathrm{C}$ for $15 \mathrm{~min}, 40$ three-step cycles $\left(94{ }^{\circ} \mathrm{C}-1 \mathrm{~min}, 68^{\circ} \mathrm{C}-1 \mathrm{~min}, 72{ }^{\circ} \mathrm{C}-1 \mathrm{~min}\right.$ ), followed by $72^{\circ} \mathrm{C}$ for $10 \mathrm{~min}$. PCR product was digested by restriction endonuclease EcoR $\mathrm{V}$ for $20 \mathrm{~h}$ at $37^{\circ} \mathrm{C}$. The products of digestion were separated on a $10 \%$ polyacrylamide gel and stained with ethidium bromide. Bands were then detected by Molecular Imager ChemiDoc ${ }^{\mathrm{TM}}$ XRS + with Image $\mathrm{Lab}^{\mathrm{TM}}$ Software (BioRad).

\section{Oxidative stress modulation}

Human peripheral blood mononuclear cells were obtained from patients of three different genotypes $(\mathrm{C} / \mathrm{C}$, $\mathrm{C} / \mathrm{T}, \mathrm{T} / \mathrm{T}$ ) and were grown in RPMI containing $10 \%$ fetal bovine serum at $37{ }^{\circ} \mathrm{C}$ in a $5 \% \mathrm{CO}_{2}$ incubator. $\mathrm{H}_{2} \mathrm{O}_{2}$ was administered to the cells in final concentrations $0.4 \mathrm{mM}$, $0.7 \mathrm{mM}$, and $1.0 \mathrm{mM}$ for $60 \mathrm{~min}$. Thereafter, the cells were harvested, washed twice with $0.15 \mathrm{mM} \mathrm{NaCl}$ solution and stored at $-20{ }^{\circ} \mathrm{C}$. The density of cells at the collection time was $1 \times 10^{6}$ cells $/ \mathrm{ml}$.

\section{Catalase activity}

Lysed peripheral blood mononuclear cells $(0.1 \mathrm{ml})$ were added to $2 \mathrm{ml} 0.03 \% \mathrm{H}_{2} \mathrm{O}_{2}$ solution. After $10 \mathrm{~min}, 1 \mathrm{ml} 4 \%$ ammonium molybdate was used to cease the reaction. Blanks consisted of distilled water. Extinction was monitored on a SF-46 spectrophotometer by changes in optical density reaction probe against blank probe at $410 \mathrm{~nm}$. Catalase activity was determined by the following formula: $\mathrm{A}=\left(\mathrm{E}_{\mathrm{b}}-\mathrm{E}_{\mathrm{s}}\right) \cdot \mathrm{V} / \mathrm{v} \cdot \mathrm{t} \cdot \mathrm{C}$ where $\mathrm{A}$ - catalase activity, $\mathrm{E}_{\mathrm{b}}$ - extinction of a blank probe, $E_{s}$ - extinction of a sample probe, $\mathrm{V}$ - total volume of the probe, $\mathrm{v}$ - sample volume, $\mathrm{t}$ - incubation time, $\mathrm{C}$ - extinction coefficient $\left(22.2 * 10^{3} \mathrm{mmol}^{-1} * \mathrm{sm}^{-1}\right)$.

\section{Statistical analysis}

Continuous variables were analyzed by independent $t$ test and were presented as means \pm S.D. The allele frequency was obtained by direct gene counting. The Hardy-Weinberg equilibrium was tested by using the $\chi^{2}$ test. The frequency distribution at catalase single nucleotide polymorphism (SNP) was tested for deviations from Hardy-Weinberg equilibrium. Statistical analysis of catalase activity was performed using Kruskal-Wallis test followed by the Mann-Whitney $\mathrm{U}$ test. The differences were considered significant when $P<0.05$.

Our results indicated that $71(69 \%)$ individuals out of 103 persons tested had $\mathrm{C} / \mathrm{C}$ genotype, while $\mathrm{C} / \mathrm{T}$ genotype was found in $26(25 \%)$ persons, $6(6 \%)$ persons were classified as $\mathrm{T} / \mathrm{T}$ homozygous mutants. Catalase $262 \mathrm{C}>\mathrm{T}$ gene polymorphism in Russian population was shown to correlate with that in HardyWeinberg equilibrium $\left(\chi^{2}=2.67, \mathrm{p}=0.10\right) \quad$ (Table 1). Catalase activity was different in cells derived from persons with various genotypes. Peripheral blood mononuclear cells from $\mathrm{C} / \mathrm{C}$ genotype individuals had the increased catalase activity when exposed to $\mathrm{H}_{2} \mathrm{O}_{2}$ concentrations, with a maximum at $0.7 \mathrm{mM}$. On the contrary, the decrease of $\mathrm{H}_{2} \mathrm{O}_{2}$-induced catalase activity was observed (Fig. 1) in $\mathrm{C} / \mathrm{T}$ and $\mathrm{T} / \mathrm{T}$ genotype individuals.

Table 1. Frequencies of $-262 C>T$ catalase genotypes in healthy donors from Russian population.

\begin{tabular}{ccccc}
\hline & Genotype & \multicolumn{2}{c}{ Allele } \\
\hline $\mathbf{C} / \mathbf{C}$ & $\mathbf{C} / \mathbf{T}$ & $\mathbf{T} / \mathbf{T}$ & $\mathbf{C}$ & $\mathbf{T}$ \\
\hline 71 & 26 & 6 & 168 & 38 \\
$69(\%)$ & $25(\%)$ & $6(\%)$ & $82(\%)$ & $18(\%)$ \\
\multicolumn{4}{c}{$\chi^{2}=2.67, p=0.10$} \\
\hline
\end{tabular}

Donors with $\mathrm{C} / \mathrm{C}$ genotype were found to be the most frequent, which is in agreement with the previous 


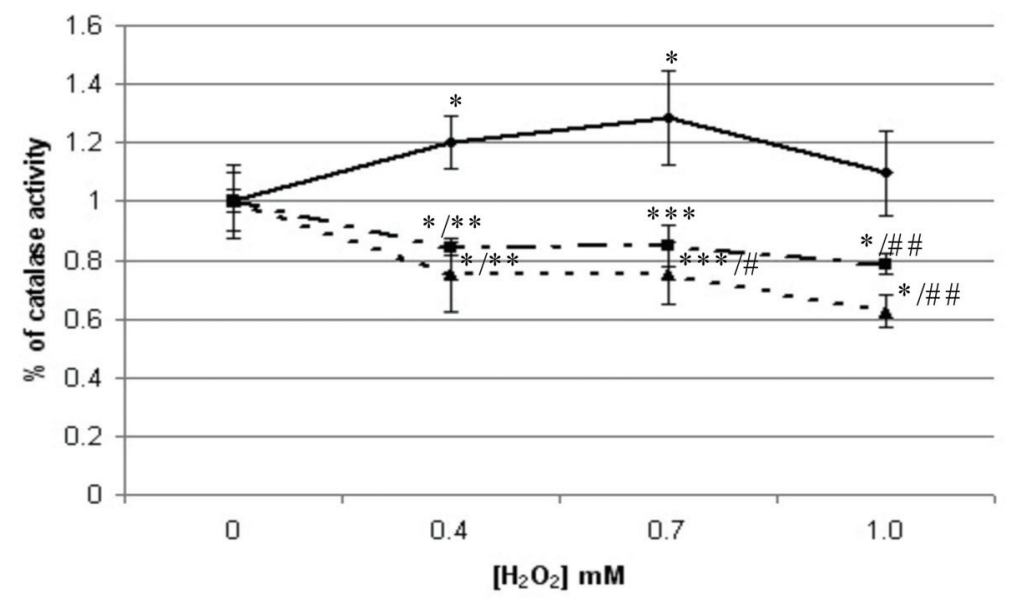

Fig. 1. Catalase gene single nucleotide polymorphism affects $\mathrm{H}_{2} \mathrm{O}_{2}$-induced catalase activity. Leukocytes from $\mathrm{C} / \mathrm{C}$ genotype $\longrightarrow \mathbf{c} / \mathbf{C}$ donors exhibit elevated catalase -1- - c/T activity in the presence of $0.4 \mathrm{mM}$ - $-\mathbf{C} / \mathbf{T}$ and $0.7 \mathrm{mM} \mathrm{H}_{2} \mathrm{O}_{2}$ for $60 \mathrm{~min}$. $\mathrm{C} / \mathrm{T}$ and $\mathrm{T} / \mathrm{T}$ allele carriers showed - -1- - T/T decreased catalase activity in leukocytes after the incubation with $\mathrm{H}_{2} \mathrm{O}_{2}$. The results are means \pm S.D. of three independent experiments. * - significant in comparison to control group $(\mathrm{a}=0.05), * *, * * *$, \#\# - significant differences from $\mathrm{C} / \mathrm{C}$ genotype group at the corresponding $\mathrm{H}_{2} \mathrm{O}_{2}$ concentrations $(\mathrm{a}=0.05),{ }^{\#}-$ significant difference from $C / T$ genotype group $(a=0.05)$.

results received for $\mathrm{C} / \mathrm{C}, \mathrm{C} / \mathrm{T}$ and $\mathrm{T} / \mathrm{T}$ in Swedish $(52 \%$, $31 \%, 7 \%$ ) and German (59.8\%, 34.2\%, 6.0\%) populations (Forsberg et al. 2001, Zarbock et al. 2007). Peripheral blood mononuclear cells with various catalase genotypes differed in their abilities to respond to oxidative stress conditions. Mutant allele carriers had a decreased catalase activity and $\mathrm{C} / \mathrm{T}$ genotype was also associated with a diminished activity of this enzyme, but it did not reach a statistical significance (Bastaki et al. 2006). Another study revealed a significantly lower basal catalase activity only in Caucasians individuals with $\mathrm{C} / \mathrm{T}$ and $\mathrm{T} / \mathrm{T}$ genotypes (Ahn et al. 2005). In our study significantly lower catalase activity was observed in $\mathrm{C} / \mathrm{T}$ and $\mathrm{T} / \mathrm{T}$ genotype carriers as compared to $\mathrm{C} / \mathrm{C}$ allele carriers during $\mathrm{H}_{2} \mathrm{O}_{2}$-induced oxidative stress. Another study revealed that single polymorphism located in promoter region can affect not only catalase expression but also its activity (Liu et al. 2010). The explanation for that could be hypothetically based upon the evidence that catalase substrate $\mathrm{H}_{2} \mathrm{O}_{2}$ can considerably affect the enzyme activity (and) to result in catalase inactivation (Gibbons et al. 2006). Consequently, a decreased catalase expression in catalase mutant allele carriers may lead to further diminishing of catalase activity.

The lack of catalase activity hinders the conversion of hydroxyl radicals and peroxide into water and oxygen. Hydroxyl radicals are referred to be the most reactive species produced in biological systems (Berlett and Stadtman 1997). Elevated levels of hydroxyl radicals have a pronounced damaging effect and account for cell injury and the development of various pathologies. The data on the influence of catalase mutant alleles on the development of pathological states are contradictory (Jiang et al. 2001, Crawford et al. 2011), but our study revealed different responses to oxidative stress in peripheral blood mononuclear cells of catalase mutant allele carriers. This fact may point to the possibility of oxidative-stress disease development (skin cancer, neurodegenerative diseases, aging etc.).

It is known that $0.5-1.0 \mathrm{mM}$ concentrations of $\mathrm{H}_{2} \mathrm{O}_{2}$ induce cell apoptosis via the loss of mitochondrial transmembrane potential and the release of cytochrome $c$ into cytoplasm (Pryor et al. 2006). It may be due to a decrease of catalase activity in $\mathrm{C} / \mathrm{C}$ genotype donors after the incubation with $1.0 \mathrm{mM} \mathrm{H} \mathrm{O}_{2}$. Similar events can be associated with the decreased catalase activity in $\mathrm{C} / \mathrm{T}$ heterozygotes and $\mathrm{T} / \mathrm{T}$ homozygotes. The individuals with this genotype may be more sensitive to oxidative stress conditions with early apoptosis initiation. The apoptosis followed by catalase insufficiency may be a very important stage in age-related disease development.

\section{Conflict of Interest}

There is no conflict of interest.

\section{References}

AHN J, GAMMON MD, SANTELLA RM, GAUDET MM, BRITTON JA, TEITELBAUM SL, TERRY MB, NOWELL S, DAVIS W, GARZA C, NEUGUT AI, AMBROSONE CB: Associations between breast cancer risk and the catalase genotype, fruit and vegetable consumption, and supplement use. Am J Epidemiol 162: 943-952, 2005. 
AHN J, NOWELL S, MCCANN SE, YU J, CARTER L, LANG NP, KADLUBAR FF, RATNASINHE LD, AMBROSONE CB: Associations between catalase phenotype and genotype: modification by epidemiologic factors. Cancer Epidemiol Biomarkers Prev 15: 1217-1222, 2006.

BASTAKI M, HUEN K, MANZANILLO P, CHANDE N, CHEN C, BALMES JR, TAGER IB, HOLLAND N: Genotype-activity relationship for Mn-superoxide dismutase, glutathione peroxidase 1 and catalase in humans. Pharmacogenet Genomics 16: 279-286, 2006.

BERLETT BS, STADTMAN ER: Protein oxidation in aging, disease, and oxidative stress. J Biol Chem 272: 2031320316, 1997.

CASP CB, SHE JX, MCCORMACK WT: Genetic association of the catalase gene (CAT) with vitiligo susceptibility. Pigment Cell Res 15: 62-66, 2002.

CHABORY E, DAMON C, LENOIR A, HENRY-BERGER J, VERNET P, CADET R, SAEZ F, DREVET JR: Mammalian glutathione peroxidases control acquisition and maintenance of spermatozoa integrity. $J$ Anim Sci 88: 1321-1331, 2010.

CRAWFORD A, FASSETT RG, COOMBES JS, KUNDE DA, AHUJA KDK, ROBERTSON IK, BALL MJ, GERAGHTY DP: Glutathione peroxidase, superoxide dismutase and catalase genotypes and activities and the progression of chronic kidney disease. Nephrol Dial Transplant 26: 2806-2813, 2011.

FORSBERG L, LYRENAS L, FAIRE U, MORGENSTERN R: A common functional C-T substitution polymorphism in the promoter region of the human catalase gene influences transcription factor binding, reporter gene transcription and is correlated to blood catalase levels. Free Radic Biol Med 30: 500-505, 2001.

FRANKO A, DOLZAN V, ARNERIC N, DODIC-FIKFAK M: Asbestosis and catalase genetic polymorphism. Arh Hig Rada Toksikol 59: 233-240, 2008.

GIBBONS NCJ, WOOD JM, ROKOS H, SCHALLREUTER KU: Computer simulation of native epidermal enzyme structures in the presence and absence of hydrogen peroxide $\left(\mathrm{H}_{2} \mathrm{O}_{2}\right)$ : potential and pitfalls. $J$ Invest Dermatol 126: 2576-2582, 2006.

JIANG Z, AKEY JM, SHI J, XIONG M, WANG Y, SHEN Y, XU X, CHEN H, WU H, XIAO J, LU D, HUANG W, JIN L: A polymorphism in the promoter region of catalase is associated with blood pressure levels. Hum Genet 109: 95-98, 2001.

KINNULA VL, EVERITT JI, MANGUM JB, CHANG L-Y, CRAPO JD: Antioxidant defense mechanisms in cultured pleural mesothelial cells. Am J Respir Cell Mol Biol 7: 95-103, 1992.

LABIÓS M, MARTÍNEZ M, GABRIEL F, GUIRAL V, DASI F, BELTRÁN B, MUÑOZ A: Superoxide dismutase and catalase anti-oxidant activity in leucocyte lysates from hypertensive patients: effects of eprosartan treatment. J Renin Angiotensin Aldosterone Syst 10: 24-30, 2009.

LIU L, LI C, GAO J, LI K, ZHANG R, WANG G, LI C, GAO T: Promoter variant in the catalase gene is associated with vitiligo in Chinese people. J Invest Dermatol 130: 2647-2653, 2010.

MAK JCW, HO SP, YU WC, CHOO KL, CHU CM, YEW WW, LAM WK, CHAN-YEUNG M: Polymorphisms and functional activity in superoxide dismutase and catalase genes in smokers with COPD. Eur Respir J 30: 684690, 2007.

PRYOR WA, HOUK KN, FOOTE CS, FUKUTO JM, IGNARRO LJ, SQUADRITO GL, DAVIES KJA: Free radical biology and medicine: it's a gas, man! Am J Physiol Regul Integr Comp Physiol 291: R491-R511, 2006.

SCHALLREUTER KU, WOOD JM: Thioredoxin reductase - its role in epidermal redox status. J Photochem Photobiol 64: 179-184, 2001.

SCHALLREUTER KU, SALEM MA, GIBBONS NC, MARTINEZ A, SLOMINSKI R, LUDEMANN J, ROKOS H: Blunted epidermal L-tryptophan metabolism in vitiligo affects immune response and ROS scavenging by Fenton chemistry, part 1: epidermal $\mathrm{H}_{2} \mathrm{O}_{2} / \mathrm{ONOO}^{-}$-mediated stress abrogates tryptophan hydroxylase and dopa decarboxylase activities, leading to low serotonin and melatonin levels. FASEB J 26: 247-2470, 2012.

ZARBOCK R, HENDIG D, SZLISKA C, KLEESIEK K, GÖTTING C: Pseudoxanthoma elasticum: genetic variations in antioxidant genes are risk factors for early disease onset. Clin Chem 53: 1734-1740, 2007. 